\title{
Logo “Petitenget Festival 2018” Dalam Budaya Postmodern
}

\author{
I Made Dwiarya Swandi ${ }^{*}$, I Wayan Swandi'2, I Wayan Mudra ${ }^{3}$ \\ 1,2,3 Program Studi Seni, Program Magister \\ Program Pascasarjana, Institut Seni Indonesia Denpasar \\ * Penulis korespondensi; Email: dwiarya96@gmail.com
}

\begin{abstract}
Abstrak
Postmodernisme adalah suatu pergerakan ide yang menggantikan ide-ide zaman modern. Dalam logo "Petitenget Festival 2018" memiliki konteks postmodern. Penelitian ini bertujuan untuk menganalisis logo "Petitenget Festival 2018" dalam budaya postmodern. Penelitian ini juga diharapkan dapat memberikan manfaat untuk memberikan informasi tentang nilai estetika postmodern dan makna yang terdapat pada logo. Teori yang digunakan adalah teori postmodern, dan estetika postmodern. Penelitian ini menggunakan metode deskriptif kualitatif. Hasil dari penelitian ini berupa bagaimana penerapan logo "Petitenget Festival" dalam konteks postmodern. Postmodern itu sendiri dapat diliht melalui nilai estetika yang memiliki idiom idiom yang terkandung di dalam logo tersebut. Idiom estetika postmodern yang paling kuat terkait kasus diatas terdapat pada idiom pastiche. Selain itu, terdapat makna denotasi dan konotasi pada logo "Petitenget Festival 2018".
\end{abstract}

Kata kunci: Postmodern, Idiom Pastiche, Logo "Petitenget Festival"

\begin{abstract}
Postmodernism is an idea movement that replaces the ideas of the modern age. The Petitenget Festival 2018 logo has a postmodern context. This study aims to analyze the Petitenget Festival 2018 logo in postmodern culture. This research is also expected to provide benefits to provide information about the postmodern aesthetic value and meaning contained in the logo. The theory used is the postmodern theory and postmodern aesthetics. This study uses the descriptive qualitative method. The results of this study will be how the application of the Petitenget festival logo in the postmodern context. Postmodern itself can be chosen through the aesthetic value which has idioms contained in the logo. The most powerful postmodern aesthetic idioms related to the above cases are in the pastiche idioms. Other than that, there are denotations and connotations in the Petitenget Festival 2018 logo.
\end{abstract}

Keywords: Postmodern, Idiom Pastiche, Petitenget Festival, Logo.

\section{Pendahuluan}

Postmodernisme adalah suatu pergerakan ide yang menggantikan ide-ide zaman modern. Zaman modern dicirikan dengan pengutamaan rasio, objektivitas, totalitas, strukturalisasi, sistematisasi, universalisasi tunggal dan kemajuan saints. Postmodern memiliki ide cita-cita, ingin meningkatkan kondisi sosial, budaya dan kesadaran akan semua realitas serta perkembangan dalam berbagai bidang. (http://eprints.dinus.ac.id/diakses pada tanggal 19/01/19). Menurut Derrida dan Baudrillard dalam Darmawan (2006: 106), postmodernisme mengambil tanda-tanda dari periode klasik dan modern untuk menciptakan satu rantai pertandaan yang baru dengan menanggalkan makna-makna konvensional untuk menghanyutkan diri dalam permainan bebas penanda-penanda. Dalam logo "Petitenget Festival 2018" memiliki nilai dalam konteks postmodern yang bisa dilihat dari unsur visualnya.
"Petitenget Festival" merupakan kegiatan acara yang diselenggarakan oleh Desa Adat Kerobokan pada tanggal 14 September - 16 September 2018 di kawasan Pura Petitenget dan Pantai Petitenget. "Petitenget Festival" ini menampilkan kegiatan seni dan budaya seperti pementasan wayang wong Kerobokan, pementasan serta penyerahan rekor muri untuk 2000 penari tenun dari 50 Banjar Se Desa Adat Kerobokan, lomba "ngelawar" serta hiburan lainnya. Menurut wawancara kepada A.A Bagus Bayu Joni Saputra selaku ketua panitia "Petitenget Festival" pada tanggal 12 Januari 2019 mengatakan paradigma atau mindset Kerobokan yang terkenal akan daerah LP (Lembaga Pemasyarakatan) akan coba diubah dalam ajang "Petitenget Festival'. Dilanjutkan, festival Petitenget baru pertama kali digelar dengan tema "Keroboan Art \& Spririts" mengangkat ikon "Bhuto Ijo" sebagai logo dari festival tersebut. 


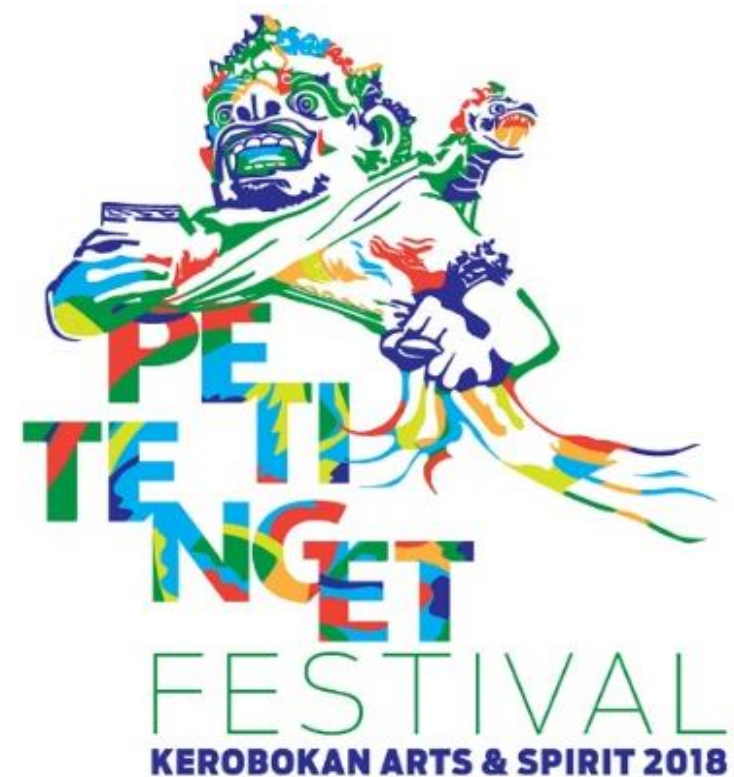

Sumber: https://www.facebook.com/PetitengetFestival

Gambar 1. Logo "Petitenget Festival"

Logo atau tanda gambar merupakan identitas yang dipergunakan untuk menggambarkan citra dan karakter suatu lembaga, perusahaan maupun organisasi (Kusrianto, 2007:232). Pada prinsipnya, logo merupakan simbol yang mewakili sosok, wajah dan eksistensi suatu perusahaan maupun organisasi. Berdasarkan komponen penyusunnya, logo dapat berupa gambar (logogram), rangkaian huruf (logotype), atau gabungan gambar dan huruf. Logo menjadi sebuah senjata utama karena berperan sebagai identitas perusahaan yang pertama kali dilihat oleh publik. Apabila dilihat dari komponen penyusunnya, maka logo "Petitenget Festival" merupakan gabungan dari logogram dan logotype yang berfungsi sebagai identitas sebuah objek wisata.

Penjelajahan mengenai nilai-nilai estetik dalam seni postmodern dapat ditelaah dari idiom-idiom estetik yang menyertainya. Idiom-idiom estetika posmodern yang diwacanakan oleh Piliang merupakan konsep estetika dari Jean Baudrillard, yang mencakup: (1) pastiche, (2) parodi, (3) kitsch, (4) camp, dan (5) skizofrenia (Pilliang, 2012: 179). Idiom estetika postmodern yang paling kuat terdapat pada idiom pastiche karena iustrasi pada logo "Petitenget Festival 2018" dalam perspektif postmodern telah mengambil 2 zaman yang bertujuan menghasilkan penafsiran makna baru. Dalam postmodernisme menghasilkan permainan penanda-penanda yang sangat bebas dan penafsiran makna yang beragam.

Dengan demikian, logo "Petitenget Festival 2018" menjadi objek yang menarik untuk diteliti karena memiliki nilai estestik dalam perspektif postmodern. Artikel ini akan membahas mengenai penerapan idiom pastiche dalam ilustrasi logo "Petitenget Festival 2018", serta makna yang terkandung di dalam "Petitenget Festival 2018".

\section{Teori Estetika Postmodern}

Estetika postmodern menurut Baudrillard (2009) adalah lebih sebagai sebuah wacana, realitas telah kehilangan dimensi rahasianya: sebatang tubuh telah kehilangan dimensi seksualnya, sebuah informasi telah kehilangan dimensi maknanya, dan sebuah karya seni telah kehilangan dimensi auranya. Segala wacana termasuk wacana seni kini tengah berupaya mencari jalannya sendiri untuk menghindarkan diri dari dialektika makna, dari dialektika komunikasi dan proses sosialisasi. Wacana estetik seni kini masukke dalam hutan rimba citra-citra dan tanda-tanda yang tanpa batas, dengan cara menghancurkan makna-makna, mengikuti batas ekstrimnya atau dengan menyajikan dimensi-dimensi yang selama ini tabu, cabul dan imoralitasnya.

Estetika dalam wacana postmodern tidak lagi membedakan mana yang indah mana yang jelek, yang bermoral dan yang amoral. Secara ekstrim dikatakan bahwa wacana estetika postmodern kini justru mencari yang terjelek di antara yang jelek. Estetika postmodern juga tidak lagi membedakan mana yang kelihatan dan yang tersembunyi. Estetika postmodern mencari yang lebih tersembunyi di antara yang paling tersembunyi.

Estetika postmoderen mencoba menyusun sebuah peta idiom-idiom estetika posmodernisme. Diharapkan dapat menjadi sebuah model dalam upaya pemahaman dan pengembangan estetika posmodern sebagai sebuah diskursus kebudayaan, sehingga bermanfaat pula bagi upaya pemahaman keserbaragaman dan pluralisme bahasa estetika terutama sejauh dipandang sebagai sebuah penandaan dan makna (Piliang, 2010:61).

Berkaitan dengan pemahaman estetika postmodern, ada lima idiom estetika yang akan dijelaskan lebih lanjut seperti pastiche, parodi, kitsch, camp, dan skizofrenia, idiom ini merupakan sebagian saja dari kemungkinan penjelalasan estetika dalam diskursus seni posmodernisme.

Pastiche adalah karya sastra yang disusun oleh elemen-elemen yang dipinjam dari berbagai penulis lain atau dari penulis tertentu di masa lalu. Sebagai karya yang mengandung unsur-unsur pinjaman, pastiche mempunyai konotasi negatif sebagai miskin kreatif, orisinalitas, keotentikan dan kebebasan. 
Parodi adalah suatu bentuk dialog (menurut pengertian Bakhtin), yaitu satu teks bertemu dan berdialog dengan teks lainnya. Tujuan parodi adalah untuk mengekspresikan perasaan tidak puas, tidak senang, tidak nyaman, berkenaan dengan intensitas gaya atau karya masa lalu yang dirujuk. Dalam kaitan ini parodi menjadi bentuk oposisi atau kontras diantara berbagai teks, karya atau gaya. Satu teks karya atau gaya dihadapkan kepada teks, karya atau gaya lainnya dengan maksud menyindir atau membuat lelucon. Maksudnya adalah kartun sebagai representasi sosial dihadapkan dengan fenomena sosial atau membawa pesanpesan sosial berkaitan dengan tema-tema pada majalah kartun "Bog-Bog".

Kitsch berasal dari bahasa Jerman "verkitschen" (membuat murah) dan "kitschen" berarti memungut sampah dari jalan. Oleh sebab itu, kitschen sering ditafsirkan sebagai sampah artistik atau selera rendah (bad taste) atau segala jenis seni palsu (pseudo-art) yang murahan dan tanpa selera, selera rendah.

Camp adalah satu idiom estetik, yang meskipun sering diperbincangkan, namun masih menimbulkan pengertian yang kontraditif. Di satu pihak sering diasiosiasikan dengan pembentukan makna. Di pihak lain justru diasiosiasikan dengan kemiskinan makna. Camp bukanlah suatu bentuk selera rendah (sampah artistik) Camp menurut Sontag (1964) adalah satu model estetisisme satu cara melihat dunia sebagai satu fenomena estetik. Namun estetik bukan dalam pengertian keindahan atau keharmonisan, melainkan dalam pengertian keartifisialan dan pengayaan. Estetisme semacam ini dipandang positif dalam peranannya pada pengembangan gaya, karena semacam pemberontakan menentang gaya elit kebudayaan tinggi.

Skizofrenia adalah istilah pada awalnya digunakan untuk menjelaskan fenomena psikis dalam diri manusia, kemudian fenomena lebih luas, yaitu fenomena bahasa (Lacan), sosial, ekonomi, sosial politik dan estetik (Piliang, 2010:187-202).Lebih lanjut dikatakan Peliang skizofrenia adalah kekacauan struktur bahasadan psikis, yaitu putusnya rantai penandaan, dimana penanda (bentuk) tidak dikaitkan dengan satu petanda (makna) dengancara yang pasti, sehingga menimbulkan kesimpangsiuran makna (Piliang, 2010-21).

\section{Teori Makna Roland Barthes}

Makna logo dilihat dari bentuknya disebut dengan makna denotasi, sedangkan makna logo yang dilihat dari konsep perancangannya disebut dengan makna konotasi. Makna denotasi merupakan hubungan eksplisit antara tanda dengan refrensi atau realitas dalam pertandaan tahap denotatif. Makna konotasi merupakan makna yang berkaitan dengan perasaan, emosi serta nilai-nilai kebudayaan dan ideology (Tinarbuko, 2009 : 19-20).

\section{Metode Penelitian}

Berdasarkan kasus di atas maka penelitian ini menggunakan metode deskriptif kualitatif. Menurut Sugiyono (2010) penelitian deskriptif merupakan penelitian yang bertujuan menggambarkan dan menginterpretasi objek yang dianalisa sesuai dengan keadaan yang sebenarnya. Penelitian ini menggunakan pendekatan kualitatif untuk menghasilkan data deskriptif berupa kata-kata. Ditambah lagi dengan melakukan wawancara dengan narasumber dan beberapa sumber pendukung guna mendapatkan hasil yang tepat. Metode ini dilakukan dengan mendeskripsikan secara lengkap budaya postmodern pada Logo "Petitenget Festival 2018", kemudian dilakukan analisis secara logis dan mendalam melalui unsur unusr visual logo.

\section{Hasil dan Pembahasan}

Tahun 1980-an, istilah postmodernisme diterapkan sebagai gaya internasional yang khas yang bukan berdasarkan pada dogma tapi berdasarkan pertemuan beraneka teori dan praktek dari para desainer di seluruh dunia. Seperti art deco, postmodern style menyatukan sejarah seni dan teknologi baru dengan kecenderungan dekoratif untuk meraih penampilan komersial yang mampu diterima oleh masyarakat.

Desain postmodern mempunyai ciri seperti geometri gerak yang suka bermain-main yang menampilkan bentuk-bentuk yang mengapung, titik dan garis yang ditempatkan secara acak, mempunyai banyak lapisan dan gambar yamg tidak lengkap, keselarasan warna-warna yang menyenangkan, tipografi dengan spasi antar huruf (letterspace) yang bertentangan dan selalu berhubungan dengan sejarah seni dan desain. Di bidang desain grafis situasinya agak khas. Di sini, istilah Post Modern dipakai untuk memayungi berbagai gejala dan trend yang terjadi sesudah para desainer jenuh dengan aturan,prosedur, dan pendekatan visual yang menjadi konvendi "modernisme akhir" (Sunarto, 2013: 132).

Logo "Petitenget Festival 2018" merupakan karya desain yang terbentuk dari beberapa unsur-unsur. Unsur-unsur tersebut kemudian saling berhubungan satu sama lain dan unsur-unsur tersebut kemudian tersusun yang dapat menimbulkan persepsi yang berbeda beda bagi audience. Dalam 
budaya postmodern logo "Petitenget Festival 2018" dapat dijelaskan dengan nilai estetika postmodern. Menurut Baudrillard (dalam Swandi, 2016:32), estetika postmodern tak lebih sebagai sebuah wacana, secara ekstrim dapat dikatakan bahwa wacana estetika postmodern kini justru mencari yang terjelek diantara yang jelek. Estetika postmodern juga tidak lagi membedakan mana yang kelihatan, mana yang tersembunyi. Estetika postmodern mencari yang lebih tersembunyi diantara yang paling tersembunyi.

Berdasarkan komponen penyusunnya, logo terdapat 3 yaitu logo berupa gambar (logogram), logo berupa tulisan (logotyp ), maupun gabungan dari logogram dan logotype. Logo dari "Petitenget Festival" ini menggunakan gabungan dari logogram dan logotype. Berkaitan dengan pemahaman estetika postmodern, idiom-idiom estetika posmodern yang diwacanakan oleh Piliang merupakan konsep estetika dari Jean Baudrillard, yang mencakup: (1) pastiche, (2) parodi, (3) kitsch, (4) camp, dan (5) skizofrenia (Pilliang, 2012: 179). Idiom estetika postmodern yang paling kuat terkait konsep diatas terdapat pada idiom pastiche. Pastiche merupakan sebuah idiom estetik yang mengandung unsur pinjaman. Logo "Petitenget Festival 2018" dalam perspektif budaya postmodern telah meminjam 2 zaman yaitu zaman seni rupa tradisi dan modern.

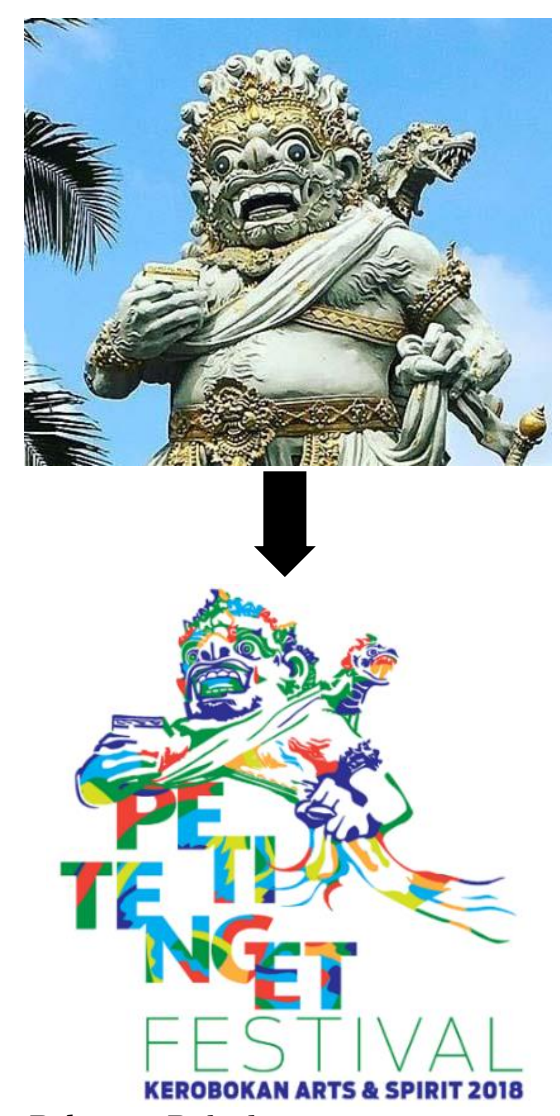

Sumber: Dokumen Pribadi

Gambar 2. Hasil peminjaman dua zaman
Seni rupa tradisi memiliki kata tradisi yang berarti adat kebiasaan turun-temurun (dari nenek moyang) yang masih dijalankan dalam masyarakat, penilaian atau anggapan bahwa cara-cara yang telah ada merupakan yang paling baik dan benar (dalam KBBI diakses pada 19/01/19). Dilihat dari ilustrasi logo, seni rupa tradisi yang dipinjam oleh ilustrasi pada logo "Petitenget Festival 2018" adalah patung berwujud Butho Ijo. Dalam mitosnya Butho ijo sangat berkaitan dengan petitenget. Butho Ijo merupakan penjaga yang ditunjuk oleh Dang Hyang Niratha untuk menjaga petitenget atau pencanangan yang merupakan benda peninggalan Dang Hyang Niratha sebelum melanjutkan perjalanan ke Uluwatu untuk mencapai moksa. Pencanangan merupakan benda suci yang berisikan ilmu pengetahuan teknologi, ekonomi,sosial, politik, dan budaya.

Zaman modern yang dipinjam atau diadopsi oleh Logo "Petitenget Festival" ini dapat dilihat dari tipografinya atau logotype. Tipografi yang digunakan adalah jenis Sans serif. Sans serif adalah jenis huruf yang tidak memiliki sirip pada ujung hurufnya dan memiliki ketebalan huruf yang sama atau hampir sama. Penggunaan jenis huruf sans serif dapat dilihat pada tulisan "Festival: dan tagline dari logo tersebut. Penggunaan jenis huruf ini bertujuan untuk menampilkan kesan modern dan sederhana. Hal ini senada diungkapan oleh Anggraini (2014:60) huruf ini melambangkan kesederhanaan, lugas, "masa kini”, dan futuristik.

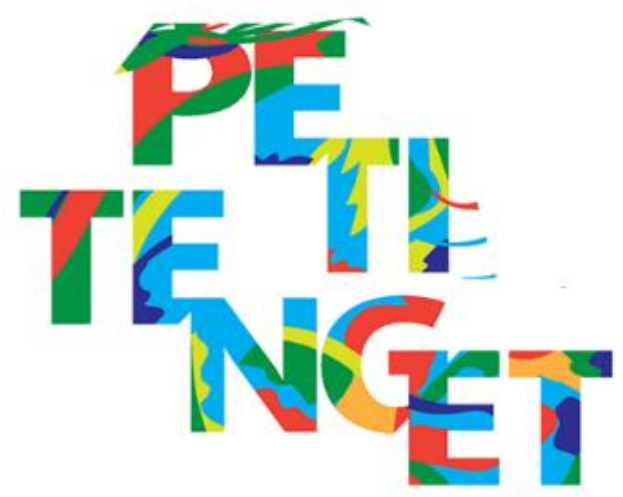

(Sumber: Dokumen Pribadi)

Gambar 3. Kesan Posmodern style pada Logotype "Petitenget Festival"

Pada logotype-nya kesan konsep postmodern style sangat jelas karena logotype dari logo "Petitenget Festival" ini tidak memperhatikan penggunaan readability, dimana jarak dan penempatan hurufnya tidak beraturan sehingga mempengaruhi kesulitan dalam membacanya. Hal ini senada diungkapkan oleh Sunarto (2013: 132) Di sini, istilah postmodern dipakai untuk memayungi berbagai gejala dan tren yang terjadi sesudah para desainer 
jenuh dengan aturan, prosedur, dan pendekatan visual yang menjadi konvendi "modernisme akhir" (Sunarto, 2013: 132).

Warna yang digunakan adalah campuran warnawarna analog dan komplementer. Dari segi warna yang digunakan pada logo "Petitenget Festival" sangat memperlihatkan budaya postmodern. Karena warna yang digunakan pada ilustrasi Logo "Petitenget Festival" ini tidak menghiraukan aturan yang berlaku. jika dilihat dari fungsionalnya penggunaan banyak warna berdampak tidak adanya point of interest atau titik fokus, namun era postmodern membatah akan hal itu. Zaman postmodern, seniman cenderung mengedepankan kebebasan dalam mengekspresikan diri dalam berkarya, mereka cenderung tidak ingin terpaku pada suatu kaidah atau tatanan standar yang berlaku. Gabungan dari kedua zaman tradisi dan modern ini yang terdapat pada estetika postmodern idiom pastiche. Kedua zaman tersebut dipinjam dan diadopsi sehingga membentuk Logo "Petitenget Festival" yang berkonsep postmodern style.

Dalam budaya postmodern logo "Petitenget Festival" dapat memberikan makna-makna akibat timbul dari permainan penanda. Postmodern mengembangkan satu prinsip baru pertandaan, yaitu form follow fun. Bukan makna-makna yang ingin dicari, melainkan kegairahan dalam bermain dengan penanda. Berdasarkan semiotika struktural yang dikembangkan Saussure, Barthes mengembangkan dua sistem pertandaan bertingkat (staggered system), yang memungkinkan untuk dihasilkannya makna yang juga bertingkat-tingkat, yang disebut sistem denotasi dan konotasi. Menurut Spradley (dalam Tinarbuko, 2009 : 19-20) makna denotasi merupakan hubungan eksplisit antara tanda dengan refrensi atau realitas dalam pertandaan tahap denotatif. Makna konotasi merupakan makna yang berkaitan dengan perasaan, emosi serta nilai - nilai kebudayaan dan ideology. Berdasarkan uraian tersebut, pemaknaan pada ilustrasi Logo "Petitenget Festival" akan dilihat dari sistem pertandaan bertingkat yang dinyatakan oleh Barthes, yaitu dengan melihat makna denotasi dan konotasinya.

Makna denotasi dari Ilustrasi Logo "Petitenget Festival" ini adalah dilihat dari tampilan visualnya yang berwujud "Butho Ijo" memiliki makna sebagai ikon atau branding dari Petitenget dan Kerobokan. Menurut Pilliang (dalam Tinarbuko, 2008:20), pada tingkat konotasi, bahasa menghadirkan kode - kode yang makna tandanya bersifat implisit, yaitu kode yang tandanya bermuatan makna-makna tersembunyi. Merujuk pada pendapat Pilliang, pemak- naan secara konotasi pada logo "Petitenget Festival" dapat dilakukan dengan melihat kodekode dengan makna tersembunyi didalamnya. Makna-makna tersebut antara lain:

a. Makna Ekonomi

Makna ekonomi yang timbul dari Logo "Petitenget Festival" dapat dilihat dari tujuan penciptaannya yaitu menjadikan "Butho Ijo" sebagai ikon Petitenget serta melestarikan seni dan budaya melalui festival. Hal ini menandakan bahwa, terdapat makna ekonomi yang ingin diperoleh dari pihak penyelenggara untuk meningkatkan ekonomi dalam sektor pariwisata.

\section{b. Makna Budaya}

Makna budaya pada logo "Petitenget Festival" ditampilkan melalui kehadiran ilustrasi logo yang berwujud "Butho Ijo" sebagai salah satu hasil kebudayaan Bali. Meskipun bentuk ilustrasi "butho ijo" disederhanakan, namun esensi tradisi "butho ijo" tetap dipertahankan dengan tetap menampilkan struktur - struktur identik butho ijo.

\section{Simpulan}

Berdasarkan hasil penelitian, analisis, dan pembahasan, penerapan budaya postmodern dapat dilihat melalui idiom pastiche estetika postmodern. Pastiche merupakan idiom yang mengadopsi dua zaman yaitu zaman seni rupa tradisi dan modern. Zaman tradisi dilihat dari logogram yang menggunakan Butho Ijo sebagai ilustrasi logo. Butho Ijo sangat erat kaitannya dengan mitos dari adanya Pura Petinget. Maka dari itu Butho Ijo dipilih sebagai ilustrasi logo "Petitenget Festival" 2018. Zaman seni rupa modern dapat dilihat dari logotype petitenget ferstival. Menggunakan jenis huruf San Serif yang tentunya berkesan modern. Namun kesan modern tersebut hilang dan menjadi kesan postmodern karena logotype "Petitenget Festival" ini tidak memperhatikan readability.

Dari segi warna yang digunakan pada logo "Petitenget Festival" sangat memperlihatkan budaya postmodern, karena warna yang digunakan pada ilustrasi logo "Petitenget Festival" ini tidak menghiraukan aturan yang berlaku. Selain itu, makna denotasi yang terdapat pada Logo "Petitenget Festival 2018" ini menjadikan Butho Ijo sebagai ikon Petitenget, Kerobokan. Pada makna konotasi mendapatkan dua pemaknaan yaitu makna ekonomi yang bertujuan meningkatkan ekonomi dalam sektor pariwisata dan makna budaya dengan menampilkan kehadiran ilustrasi "Butho Ijo" yang merupakan salah satu hasil kebudayaan Bali. 


\section{Daftar Pustaka}

Kusrianto, Adi. (2007). Pengantar Desain Komunikasi Visual. Yogyakarta: ANDI.

Pilliang, Yasraf Amir. (2010). Hypersemiotika: Tafsir Cultural Studies Atas Matinya Makna. Yogyakarta: Jalasutra.

Pilliang, Yasraf Amir. (2012). Semiotika dan Hypersemiotika. Bandung: Matahari.

Sugiyono. (2010). Metode Penelitian Pendidikan: Pendekatan Kuantitatif, Kualitatif dan R \& D). Bandung: Alfabeta.

Sunarto, Wargiono. (2013). Gaya Desain: Tinjauan Sejarah. Jakarta : Pascasarjana IKJ.
Tinarbuko, Sumbo. (2009). Semiotika Komunikasi Visual. Yogyakarta: Jalasutra.

Darmawan, Ferry. (2006). Posmodernisme Kode Visual Dalam Iklan Komersial. Diunduh 25/06/19 dari https://ejournal.unisba.ac.id/ index.php/mediator/article/view/1219 , Jurnal PRABANGKARA. Vol. 21, No. 2 Desember 2017, pp. 68-79 diakses pada tanggal 08/01/19

Kamus Besar Bahasa Indonesia. (25 juni 2019). Tradsi. https://kbbi.web.id/tradisi

Desertasi Swandi (25 juli 2019). Estetika Postmodern. http://eprints.dinus.ac.id/ diakses pada tanggal 25/06/19. 